\title{
Pelaksanaan Pemenuhan Hak Atas Aksesibilitas Pendidikan Tinggi Bagi Penyandang Disabilitas Di Yogyakarta
}

\author{
Eko Riyadi \\ Fakultas Hukum Universitas Islam Indonesia Yogyakarta Indonesia \\ Jln. Tamansiswa No. 58 Yogyakarta Indonesia \\ eko.riyadi@uii.ac.id
}

Received: 30 November 2020; Accepted: 2 Maret 2021; Published: 16 Maret 2021

DOI: 10.20885/iustum.vol28.iss1.art4

\begin{abstract}
There are two backgrounds to this research, namely the mandate of the Convention on the Rights of Persons with Disabilities and Law Number 8 of 2016 to provide inclusive education for persons with disabilities, and conditions of higher education services and facilities that are not yet suitable for access for persons with disabilities. This research was conducted to answer two questions, first, how is the portrait of the fulfillment of the right to education for persons with disabilities in tertiary institutions in Yogyakarta? Second, how is the analysis of human rights law on the practice of fulfilling the right to education for persons with disabilities at universities in Yogyakarta? The answer to this question is done by conducting empirical research. This study concludes that the accessibility of high education for persons with disabilities is still very low. Educational services and infrastructure still prevent persons with disabilities from gaining access to higher education. This also shows that higher education has not been able to fulfill the right to education for persons with disabilities. In the future, it is time for higher education providers to prepare aspects of services and infrastructure that are accessible for persons with disabilities.
\end{abstract}

Key Words: Accessibility; higher education; persons with disabilites

\section{Abstrak}

Ada dua latar belakang penelitian ini yaitu perintah Konvensi tentang Hak Penyandang Disabilitas dan Undang-Undang Nomor 8 Tahun 2016 untuk menyelenggarakan pendidikan inklusi bagi penyandang disabilitas, dan kondisi layanan dan fasilitas pendidikan tinggi yang belum layak akses bagi penyandang disabilitas. Penelitian ini dilakukan untuk menjawab dua pertanyaan yaitu, pertama, bagaimana potret pemenuhan hak atas pendidikan bagi penyandang disabilitas pada perguruan tinggi di Yogyakarta?, Kedua, bagaimana analisis hukum hak asasi manusia atas praktik pemenuhan hak atas pendidikan bagi penyandang disabilitas pada perguruan tinggi di Yogyakarta? Jawaban pertanyaan tersebut dilakukan dengan melakukan penelitian empiris. Kajian ini menyimpulkan bahwa aksesibilitas pendidikan tinggi bagi penyandang disabilitas masih sangat rendah. Layanan dan sarana prasarana pendidikan masih menghambat penyandang disabilitas untuk mendapatkan akses pendidikan tinggi. Hal ini sekaligus menunjukkan bahwa pendidikan tinggi belum mampu memenuhi hak atas pendidikan bagi penyandang disabilitas. Ke depan,sudah saatnya penyelenggara pendidikan tinggi untuk mempersiapkan aspek layanan dan sarana prasarana yang aksesibel bagi penyandang disabilitas.

Kata-kata Kunci: Aksesbilitas; pendidikan tinggi; penyandang disabilitas 


\section{Pendahuluan}

Penelitian ini didasari oleh dua pertimbangan penting, yaitu pertimbangan normatif dan pertimbangan empirik. Pertimbangan normatif yang dimaksud adalah terkait dengan telah diratifikasinya United Nation Convention on the Rights of Person with Disabilities (UNCRPD) oleh pemerintah Indonesia dengan UndangUndang Nomor 19 Tahun 2011 dan diikuti dengan disahkannya Undang-Undang Nomor 8 Tahun 2016 tentang Penyandang Disabilitas. Berdasar pada Pasal 4 ayat (1) dan (2) Konvensi, Negara Pihak berkewajiban mengambil langkah dalam rangka memastikan dan mempromosikan pelaksanaan penuh atas semua hak dan kebebasan penyandang disabilitas tanpa diskriminasi.

Pasal 24 ayat (1) Konvensi menegaskan bahwa Negara Pihak dalam hal pendidikan berkewajiban untuk mengakui hak atas pendidikan bagi penyandang disabilitas. Pengakuan ini diperlukan untuk pemenuhan hak atas pendidikan bagi penyandang disabilitas yang didasarkan pada prinsip kesetaraan kesempatan. Negara Pihak juga berkewajiban memastikan pendidikan inklusif tersedia pada semua level pendidikan. Artinya, pendidikan harus tersedia, mulai dari pendidikan dasar hingga pendidikan tinggi. Hal ini diperkuat dengan perintah Pasal 24 ayat (5) UNCRPD bahwa Negara Pihak wajib memastikan semua penyandang disabilitas mampu mengakses pendidikan dasar, pendidikan vokasional, pendidikan orang dewasa, dan pendidikan seumur hidup tanpa diskriminasi.

Ketentuan di atas diperkuat oleh perundang-undangan domestik. Pemerintah Indonesia telah berjanji bahwa pelayanan terhadap penyandang disabilitas didasarkan pada beberapa prinsip penting seperti penghormatan terhadap martabat, otonomi individu, tanpa diskriminasi, partisipasi penuh, keragaman manusia dan kemanusiaan, kesamaan kesempatan, kesetaraan, aksesibilitas, kapasitas yang terus berkembang dan identitas anak, inklusif, dan perlakuan khusus dan perlindungan lebih. ${ }^{1}$ Terkait pendidikan, pemerintah juga telah mengakui bahwa penyandang disabilitas berhak atas pendidikan dengan prinsip bahwa pendidikan tersebut harus tersedia di semua jenis, jalur, dan jenjang pendidikan; penyandang disabilitas memiliki kesamaan kesempatan

\footnotetext{
${ }^{1}$ Pasal 2 Undang-Undang Nomor 8 Tahun 2016 tentang Penyandang Disabilitas
} 
untuk menikmati layanan pendidikan maupun menyelenggarakan pendidikan dan penyandang disabilitas memiliki hak untuk mendapatkan akomodasi yang layak pada lembaga pendidikan. ${ }^{2}$

Berdasarkan data dari World Health Organization (WHO) dan The UN Economic and Social Council for The Asia Pasific (UNESCAP) pada 2015, jumlah penyandang disabilitas di Indonesia secara empiris menempati posisi tertinggi jika dibandingkan negara-negara lain di ASEAN. Secara berurutan, jumlah warga penyandang disabilitas adalah Indonesia dengan jumlah 20.605.120 orang, Brunei Darussalam 4.148 orang, Filipina 1.442 .586 orang, Malaysia 359.203 orang, Singapura 100.000 orang, Thailand 1.478.662 orang, dan Kamboja 301.629 orang. Survei Penduduk Antar Sensus (SUPAS) 2015 di Indonesia menyatakan bahwa jumlah penyandang disabilitas adalah sebesar 8\% dari total populasi 257.564.000. Sementara negara-negara lain di ASEAN berkisar di angka 1,1\% - 3\% dari total populasi. ${ }^{3}$

Belum ada survei yang cukup akurat di Indonesia untuk melihat seberapa banyak penyandang disabilitas yang mengakses pendidikan, baik pendidikan dasar, menengah, atas dan tinggi, pada jalur pendidikan umum. Hal ini terkait dengan kebijakan pemerintah sejak lama yang memosisikan penyandang disabilitas sebagai orang-orang khusus yang diarahkan pada pendidikan khusus dengan nama Sekolah Luar Biasa (SLB). ${ }^{4}$ Model sekolah yang segregatif ini bahkan pernah dianggap sebagai kebijakan yang baik. ${ }^{5}$ Persepsi ini muncul karena kurangnya pengetahuan penyelenggara pendidikan tinggi ditambah lemahnya kesadaran akan hak bagi penyandang disabilitas. Kebijakan pengkhususuan ini dikritik karena memaksakan penyandang disabilitas mengikuti program pendidikan yang belum tentu sesuai dengan kemampuan dan

\footnotetext{
2 Pasal 10 Undang-Undang Nomor 8 Tahun 2016 tentang Penyandang Disabilitas

http://www2.agendaasia.org/index.php/information/disability-in-asean/88-disability-in-southeastasian-countries, diakses pada 24 September 2019

${ }^{4}$ Eta Yuni Lestari, Slamet Sumarto dan Noorochmat Isdaryanto, "Pemenuhan Hak Bagi Penyandang Disabilitas Di Kabupaten Semarang Melalui Implementasi Convention On The Rights Of Persons With Disabillities (CPRD) Dalam Bidang Pendidikan”, Jurnal Integralistik, Vol. 28, Nomor 1, 2017. Data yang lain dapat dibaca pada Mudhafar Anzari, A Hamid Sarong, M. Nur Rosyid, "Hak Memperoleh Pendidikan Inklusif terhadap Penyandang Disabilitas", Syiah Kuala Law Journal, Vol. 2(1), April 2018

${ }^{5}$ Indah Triutari, "Persepsi Mahasiswa Disabilitas tentang Sistem Pendidikan Segregasi dan Pendidikan Inklusi, Despkriptif Kuantitatif pada Penyandang Disabilitas di Universitas Negeri Padang”, Juppekhu Jurnal Penelitian Pendidikan Khusus, Vol. 3 Nomor 3, 2014
} 
keinginan penyandang disabilitas. Untuk menjawab persoalan tersebut, aktivis sosial mendorong didirikannya sekolah inklusif untuk memfasilitasi penyandang disabilitas mendapatkan pendidikan setara dengan orang tanpa disabilitas. ${ }^{6}$ Data yang pernah ada adalah bahwa di DIY, pada 2011, terdapat sebanyak 98 orang. ${ }^{7}$

Perlu pengujian lebih jauh mengapa angka penyandang disabilitas yang mengakses pendidikan tinggi sangat rendah. Penelitian ini dilakukan untuk memotret kesiapan perguruan tinggi dalam menyelenggarakan pendidikan bagi penyandang disabilitas.

\section{Rumusan Masalah}

Berdasarkan latar belakang sebagaimana dijelaskan di atas, rumusan masalah penelitian ini yaitu pertama, bagaimana pelaksanaan pemenuhan hak atas pendidikan bagi penyandang disabilitas pada perguruan tinggi di Yogyakarta? Kedua, bagaimana analisis hukum hak asasi manusia atas praktik pemenuhan hak atas pendidikan bagi penyandang disabilitas pada perguruan tinggi di Yogyakarta?

\section{Tujuan Penelitian}

Berdasarkan rumusan masalah di atas, tujuan penelitian ini adalah, pertama, untuk mengetahui pelaksanaan pemenuhan hak atas pendidikan bagi penyandang disabilitas pada perguruan tinggi di Yogyakarta. Kedua, untuk merumuskan analisis hukum hak asasi manusia atas praktik pemenuhan hak atas pendidikan bagi penyandang disabilitas pada perguruan tinggi di Yogyakarta.

\section{Metode Penelitian}

Penelitian ini adalah penelitian hukum empiris. Objek penelitiannya adalah bagaimana perguruan tinggi di Yogyakarta memberikan layanan dan melengkapi sarana prasarana yang aksesibel bagi penyandang disabilitas sebagaimana diperintahkan oleh Undang-Undang Nomor 8 Tahun 2016 tentang Penyandang Disabilitas. Penelitian dilakukan pada enam perguruan tinggi di Yogyakarta antara lain Universitas Islam Indonesia (UII), Universitas Gajah Mada (UGM),

6 Jazim Hamidi, "Perlindungan Hukum terhadap Disabilitas dalam Memenuhi Hak Mendapatkan Pendidikan dan Pekerjaan”, Jurnal Hukum Ius Quia Iustum, Volume 23 Issue 4, Oktober 2016

7 Ahmad Soleh, "Kebijakan Perguruan Tinggi Negeri Yogyakarta terhadap Penyandang Disabilitas", Jurnal Pendidikan Islam, Volume IIII, Nomor 1, Juni 2014/1435 
Universitas Islam Negeri Sunan Kalijaga Yogyakarta (UIN), Universitas Negeri Yogyakarta (UNY), Universitas Muhammadiyah Yogyakarta (UMY) dan Universitas Atma Jaya Yogyakarta (UAJY). Enam perguruan tinggi tersebut telah terakreditasi unggul sehingga layak dijadikan patokan standar tinggi untuk mengukur bagaimana komitmen perguruan tinggi dalam pemenuhan hak atas pendidikan bagi penyandang disabilitas.

\section{Hasil Penelitian dan Pembahasan}

\section{Standar Kewajiban Perguruan Tinggi dalam Pemenuhan Hak Atas Pendidikan Bagi Penyandang Disabilitas}

\section{Hak Asasi Manusia dan Penyandang Disabilitas}

Hak asasi manusia adalah hak yang melekat pada diri manusia semata karena ia adalah manusia dan bukan karena pemberian hukum positif. ${ }^{8}$ Fokus utamanya adalah pada kehidupan dan martabat manusia. ${ }^{9}$ Martabat ini akan terganggu apabila ia menjadi korban dengan tidak dipenuhi hak-haknya. ${ }^{10}$ Hak asasi manusia tidak terbatasi oleh warna kulit, jenis kelamin, bahasa, budaya, dan kewarganegaraan yang berbeda-beda. Hak ini lahir dari teori hukum alam dan keinginan untuk membangun ketertiban universal. ${ }^{11}$ Universalitas itu telah diikuti dengan penciptaan mekanisme penegakan hak asasi manusia secara komprehensif melalui pelembagaan di Perserikatan Bangsa-Bangsa. ${ }^{12}$

Berdasar teori kontrak sosial, negara adalah pihak yang berkewajiban untuk memenuhi hak asasi manusia. Hukum hak asasi manusia meletakkan individu

\footnotetext{
${ }^{8}$ Jack Donnely, Universal Human Rights in Theory and Practice, Cornell University Press, Ithaca and London, 2003, hlm. 7-21. Lihat juga Knut D. Asplund, Suparman Marzuki, Eko Riyadi (ed), Hukum Hak Asasi Manusia, Pusham UII, Yogyakarta, 2008, hlm. 11

9 Manfred Nowak, Introduction to the International Human Rights Regime, Martinus Nijhoff Publishers, Leiden/Boston, 2002, hlm. 1

10 Puguh Windrawan (ed.), Aksesibilitas Peradilan Bagi Penyandang Disabilitas, Pusham UII, Yogyakarta, 2015, hlm. 17

${ }^{11}$ Henry J. Steiner dan Philip Alston, International Human Rights in Context: Law, Politics, Morals, Oxford University Press, New York, 2000, hlm. 324

12 Sir Nigel Rodley, 'United Nation Human Rights Treaty Bodies and Special Procedures of the Commission on Human Rights-Compementary or Competition', dalam Nisuke Ando (ed.), Toward Implementing Universal Human Rights, Festshrift for the Twenty-Fifth Anniversary of the Human Rights Committee, Martinus Nijhoff Publishers, The Netherland, 2004, hlm. 9
} 
sebagai pemangku hak (rights holder) dan negara sebagai pemangku kewajiban (duty bearer). ${ }^{13}$

Hukum hak asasi manusia mengatur bahwa negara memiliki tiga kewajiban yaitu menghormati (to respect), melindungi (to protect), dan memenuhi (to fulfill). ${ }^{14}$ Kesengajaan atau kegagalan negara dalam menghormati, melindungi, dan memenuhi tiga kewajiban tersebut akan menyebabkan negara dapat dituntut karena melanggar hak asasi manusia. Ketidakmauan (unwilingness) dan ketidakmampuan (unability) negara untuk melindungi dan memenuhi disebut sebagai pelanggaran hak asasi manusia pasif (human rights violation by omission). Kegagalan negara untuk menghormati disebut sebagai pelanggaran hak asasi manusia aktif (human rights violation cy comission). 15

Hukum hak asasi manusia telah memberikan jaminan lengkap atas semua kategori hak asasi manusia. Secara internasional, Perserikatan Bangsa-Bangsa telah mengesahkan sepuluh instrumen pokok hak asasi manusia. ${ }^{16}$ Instrumen paling anyar adalah Konvensi tentang Hak Penyandang Disabilitas (Convention on the Rights of Person with Disabilities). ${ }^{17}$ Konvensi ini didorong oleh debat panjang, salah satunya dengan disahkannya Rehabilitation Act 1973 oleh pemerintah Amerika Serikat dan diadopsinya Standard Rules on on the Equalization of Opportunities for Persons with Disabilities pada 1993 oleh Majelis Umum Perserikatan Bangsa-Bangsa. ${ }^{18}$ Merespon telah diadopsinya Konvensi dan pascaratifikasinya, pemerintah Indonesia telah mengesahkan instrumen domestik yaitu Undang-Undang Nomor 8 Tahun 2016 tentang Penyandang Disabilitas.

13 Thomas Buergenthal, International Human Rights In Nutshell, A Thomson Company, United State of America, 2002, hlm. 2

${ }^{14}$ Eko Riyadi, Hukum Hak. Asasi Manusia, Perspektif Internasional, Regional dan Nasional, Rajawali Press, Depok, 2018, hlm. 69-71

15 Ibid., hlm. 72.

16 Kesepuluh instrumen tersebut antara lain Deklarasi Universal Hak Asasi Manusia, Kovenan Internasional tentang Hak Sipil dan Politik, Kovenan Internasional tentang Hak Ekonomi, Sosial dan Budaya, Konvensi Internasional tentang Penghapusan Segala Bentuk Diskriminiasi Rasial, Konvensi tentang Penghapusan Segala Bentuk Diskriminasi terhadap Perempuan, Konvensi Menentang Penyiksaan dan Perlakuan atau Penghukuman Lain yang Kejam, Tidak Manusiawi dan Merendahkan Martabat, Konvensi tentang Hak Anak, Konvensi tentang Perlindungan Pekerja Migran dan Keluarga Mereka, Konvensi Internasional tentang Perlindungan Semua Orang dari Penghilangan Secara Paksa, dan Konvensi tentang Hak Penyandang Disabilitas

17 Konvensi ini diadopsi oleh Perserikatan Bangsa-Bangsa pada 13 Desember 2006 dengan Resolusi Majelis Umum A/RES/61/106. Indonesia kemudian meratifikasi dengan Undang-Undang Nomor 19 Tahun 2011 pada 10 November 2011

${ }^{18}$ Luke Clement dan Janet Read (ed.), Disabled People and the Right to Life: the Protectin and Violation of Disabled People's Most Basic Human Rights, Rotledge Taylor \& Francis Group, London \& New York, 2008, hlm. 15 
Konvensi memberikan pijakan kuat bahwa setiap penyandang disabilitas memiliki hak atas pendidikan. Pada konteks pendidikan, Negara Pihak diberi kewajiban untuk memastikan pendidikan inklusif ditujukan untuk tiga hal yaitu (a) mengembangkan potensi dan rasa kemanusiaan serta kepercayaan dirinya, (b) mengembangkan penyandang disabilitas sesuai dengan talenta dan kreativitasnya, dan (c) memungkinkan penyandang disabilitas terlibat aktif pada kehidupan sosialnya. ${ }^{19}$

\section{Hak Atas Pendidikan Bagi Penyandang Disabilitas}

Pendidikan adalah hak asasi manusia. ${ }^{20}$ Hak atas pendidikan dianggap sebagai salah satu hak paling dasar dalam keluarga hak ekonomi, sosial, dan budaya. Jaminan hak atas pendidikan telah ditegaskan di dalam Pasal 28C ayat (1) UUDNRI 1945 yang berbunyi:21

Setiap orang berhak mengembangkan diri melalui pemenuhan kebutuhan dasarnya, berhak mendapat pendidikan dan memperoleh manfaat dari ilmu pengetahuan dan teknologi, seni dan budaya, demi meningkatkan kualitas hidupnya dan demi kesejahteraan umat manusia

Pasal 32 Undang-Undang Nomor 12 Tahun 2012 tentang Pendidikan Tinggi memberikan ketentuan bahwa Program Studi pada sebuah perguruan tinggi diberi kewenangan untuk menyelenggarakan pendidikan khusus bagi mahasiswa yang memiliki kesulitan mengikuti pembelajaran dan/atau mahasiswa dengan potensi kecerdasan dan bakat istimewa. Ketentuan pada Pasal ini terlihat masih menggunakan paradigma pengkhususan dan bukan pendidikan inklusi. Ketentuan ini selayaknya diharmonisasikan dengan ketentuan yang baru yaitu Konvensi tentang Hak Penyandang Disabilitas ${ }^{22}$ dan Undang-Undang Nomor 8 Tahun 2016 tentang Penyandang Disabilitas.

Pasal 24 Konvensi tentang Hak Penyandang Disabilitas memberikan ketentuan sebagai patokan dalam penyelenggaraan pendidikan. Penyandang

\footnotetext{
${ }^{19}$ Pasal 24 Konvensi tentang Hak Penyandang Disabilitas

${ }^{20}$ Prinsip-Prinsip Limburg Bagi Implementasi Perjanjian Internasional Mengenai Hak Ekonomi, Sosial dan Budaya

21 Ketentuan ini juga dapat dibaca pada 12 Kovenan Internasional tentang Hak Ekonomi, Sosial dan Budaya dan Pasal 12 Undang-Undang Nomor 39 Tahun 1999 tentang Hak Asasi Manusia

${ }^{22}$ Sebagaimana telah diratifikasi oleh Pemerintah Indonesia dengan Undang-Undang Nomor 19 Tahun 2019 tentang Pengesahan Convention on the Rights of Persons with Disabilites (Konvensi tentang Hak Penyandang Disabilitas)
} 
disabilitas tidak boleh dikeluarkan dari sekolah umum pada semua level pendidikan. Layanan pendidikan harus disediakan secara inklusif yang memungkinkan penyandang disabilitas mengakses seluruh fasilitasnya. Lembaga pendidikan harus mengembangkan akomodasi yang layak (reasonable accomodation) agar dapat diakses secara setara. Pendidikan juga harus mengembangkan sistem yang mendukung atas keanekaraman kebutuhan setiap peserta didik. Penyelenggara pendikan juga harus menyediakan guru yang memiliki kemampuan mendidik dan fasilitas yang memadai agar penyandang disabilitas dapat memperoleh pengetahuan dan keterampilan sesuai dengan bakat dan kemauannya. Prinsip penting yang lain adalah bahwa negara dan lembaga pendidikan memiliki kewajiban untuk memastikan proses pendidikan sepanjang hayat (lifelong learning) tanpa diskriminasi. ${ }^{23}$

Pendidikan harus diselenggarakan secara inklusif. Pendidikan inklusif dimaknai bahwa semua murid, baik murid dengan disabilitas dan tanpa disabilitas, dengan semua jenis kemampuan belajar bersama dalam satu lingkungan kelas. ${ }^{24} \mathrm{Hal}$ ini termasuk menciptakan sistem pendidikan yang semua orang dapat belajar bersama dan kebutuhan individualnya terpenuhi. Fokus pendidikan inklusi adalah pada kualitas pendidikan bagi semua orang, memastikan penyelenggara pendidikan seperti sekolah maupun universitas dapat mendukung semua murid untuk mencapai luaran yang terbaik dan mereka dapat berpartisipasi secara penuh. Pendidikan inklusi ini beda dengan pengecualian (exclusion), pemisahan (segregation), dan penyatuan (integration) yaitu saat anak dengan disabilitas dipisahkan ruangannya atau ditempatkan di kelas umum tanpa dukungan akomodasi yang layak.

Fitur utama dari pendidikan inklusi antara lain adanya komitmen kepemimpinan untuk menyediakan layanan pendidikan inkulsi, pengakuan bahwa semua orang memiliki kemampuan untuk belajar, dan oleh karenanya guru, lingkungan, dan fasilitas harus dibuat secara memadai. ${ }^{25}$

${ }^{23}$ Pasal 24 Konvensi

${ }^{24}$ Komentar Umum No. 4 terhadap Pasal 24 Konvensi tentang Hak Penyandang Disabilitas terkait Hak atas Pendidikan Inklusi

25 Ibid. 
Pentingnya akses pendidikan bagi penyandang disabilitas juga telah dimunculkan sejak 1993 dalam Standard Rules on the Equalisation of Opportunities for Persons with Disabilities. Standar ini menegaskan bahwa penyandang disabilitas harus diberi akses untuk mendapatkan pendidikan bersama dengan orang tidak dengan disabiltas pada semua jalur dan jengang pendidikan. ${ }^{26}$ Di ranah domestik, pada Pasal 43 ayat (1) Undang-Undang Nomor 8 Tahun 2016 tentang Penyandang Disabilitas dinyatakan bahwa setiap penyelenggara pendidikan tinggi wajib memfasilitasi pembentukan Unit Layanan Disabilitas. Unit inilah yang didorong menjadi taks force percepatanan aksesibilitas pendidikan tinggi bagi penyandang disabilitas.

\section{Aksesibilitas Pendidikan Tinggi bagi Penyandang Disabilitas}

Aksesibilitas adalah kemudahan akses untuk mewujudkan kesamaan kesempatan bagi penyandang disabilitas dengan manusia pada umumnya. Semua hambatan sarana prasarana dan layanan yang selama ini menyulitkan, mengucilkan, dan meniadakan hak-hak penyandang disabilitas harus dibenahi. Akesesibilitas menghendaki lingkungan yang ramah dan memudahkan mobilitas semua orang.

Terdapat setidaknya dua hal yang harus dijamin kualitasnya untuk mewujudkan lingkungan yang ramah dan aksesibel bagi semua orang, yaitu kualitas aksesibilitas dan mobilitas. Aksesibilitas dimaknai sebagai kemudahan yang tidak hanya mengacu pada lingkungan fisik tetapi juga terkait sikap dan perlakuan masyarakat kepada penyandang disabilitas. Kualitas mobilitas dimaknai sebagai kemampuan untuk bergerak atau digerakkan. ${ }^{27}$

Terdapat empat prinsip terkait dengan konsep aksesibilitas yang telah dirumuskan oleh United Nations Economic and Social Commision for Asia and the Pasific (UNESCAP). Pertama, kemudahan untuk mencapai sebuah tempat. Kedua, kemudahan untuk masuk ke dalam suatu tempat atau lingkungan. Ketiga, kemudahan untuk mempergunakan semua fasilitas yang ada. Keempat,

\footnotetext{
${ }^{26}$ Rebecca M.M. Wallace and Kenneth Dale-Risk, International Human Rights, Text and Materials, Sweet \& Maxwell, A Thomson Company, London, 2001, hlm. 207 hlm. 278

${ }^{27}$ Harry Kurniawan, “Aksesibilitas Infrastruktur Bagi Difabel”, Jurnal Difabel, Volume 2, No. 2, 2015 ,
} 
kemampuan untuk mencapai, masuk, dan mempergunakan tanpa menjadi objek belas kasihan. ${ }^{28}$

Aksesisibilitas pendidikan tinggi pada penelitian ini dimaknai sebagai pendidikan tinggi dapat diakses oleh penyandang disabilitas baik secara fisik maupun layanan akomodasinya yang layak. Secara operasional, aksesibilitas pendidikan tinggi didefinisikan tatkala penyelenggara pendidikan tinggi mampu menghilangkan hambatan yang potensial atau telah dihadapi oleh penyandang disabilitas.

Penelitian ini meletakkan konsep bahwa disabilitas bukanlah ketidaksempurnaan, baik fisik maupun psikis, yang dialami seseorang. Disabilitas adalah adanya hambatan yang dihadapi setiap orang yang memiliki keterbatasan fisik, intelektual, mental, dan/atau sensorik. ${ }^{29}$ Titik fokusnya adalah pada hambatan. Maka, semua konsep layanan pendidikan harus diorientasikan untuk mengurangi bahkan menihilkan hambatan yang mungkin atau telah dihadapi oleh penyandang disabilitas. Hambatan tersebut antara lain hambatan sarana fisik mobilitas, habatan perilaku, hambatan hukum dan prosedur, hambatan teknologi informasi dan komunikasi, dan hambatan sumber daya. ${ }^{30}$

\section{Potret Pemenuhan Hak atas Pendidikan Bagi Penyandang Disabilitas pada Perguruan Tinggi di Yogyakarta}

Ya memang kebanyakan belum ya, Cuma di tingkat Universitas sudah kami bicarakan itu dengan para pimpinan. Ini karena ternyata ada penyandang disabilitas, seperti low vision lalu cacat tubuh, lalu mungkin pembelajaran khusus bagi disabilitas rungu, jadi kita usahakan adakan. ${ }^{31}$

Pernyataan ini mewakili kondisi makro situasi kesiapan perguruan tinggi dalam memenuhi hak atas pendidikan bagi penyandang disabilitas. Perguruan tinggi baru sebatas merespon kebutuhan spesifik yang bersifat kasuistis bagi mahasiswanya yang penyandang disabilitas, dan belum menerapkan konsep

${ }_{28}$ Ibid, lihat juga di http://www.dinf.ne.jp/doc/english/intl/z15/z15009gl/z1500901. html diakses 17 September 2019. Hal yang relatif sama dinyatakan dalam Komentar Umum Nomor 4 dan Pasal 18 UndangUndang Nomor 8 Tahun 2016

${ }^{29}$ Pasal 1 Undang-Undang Nomor 8 Tahun 2016 tentang Penyandang Disabilitas

30 Puguh Windrawan (ed.), ... Op. Cit., hlm. 60-77

31 Wawancara dengan Triyana (Wadek 1 Fakultas Hukum Universitas Atma Jaya Yogyakarta), tanggal 20 November 2019 
inklusif. Beberapa indikator besar yang ditemukan akan diuraikan pada penjelasan berikut.

\section{Tersedia Fasilitas Aksesibilitas yang Belum Sesuai Standar}

Perguruan tinggi di Yogyakarta memperlihatkan semangat untuk memberikan akses mobilitas bagi penyandang disabilitas juga dalam rangka memenuhi prasyarat akreditasi. Jalan landai dengan ramp, guiding block, serta toilet aksesibel dibangun. Perubahan dan penambahan fasilitas tersebut tampak tidak didasarkan pada perencanaan yang memadai. Jalan landai dengan ramp dibangun di pintu masuk dengan kemiringan yang beragam dan tidak ada eskalator atau lift untuk menuju lantai dua atau tiga. ${ }^{32}$ Pengguna kursi roda dapat memasuki area kampus namun tidak bisa mengakses ruang kelas yang ada di lantai dua. Akses menuju lantai bertingkat masih menggunakan tangga. Tersedia lift, namun hanya ada di beberapa gedung yang biasanya dekat dengan pusat administrasi kampus. Akses menuju lift juga seringkali masih terhambat lantai berundak dan belum rata.

Guiding block juga dipasang di area depan kampus, namun tidak ada skema utuh di seluruh area kampus. ${ }^{33}$ Demikian juga toilet, hal yang dilakukan adalah dengan menambah satu ruang dengan toilet duduk, namun pintunya tetap menghambat pengguna kursi roda untuk mengaksesnya. ${ }^{34}$ Perguruan tinggi menyadari kewajiban penyediaan akses yang inklusif, namun ada kendala anggaran dan pertimbangan penduduk kampus dengan disabilitas yang masih minoritas. Situasi ini merata di perguruan tinggi dan dapat diwakili dengan pernyataan Waryono berikut: 35

Memang kami masih ada beberapa kekurangan, tapi tentunya ini sembari berjalan melihat penduduk kampus yang tergolong disabilitas secara jumlah masih minoritas dibanding yang non disabilitas. Jadi tetap yang kita utamakan layanan umum.

\footnotetext{
32 Standar kemiringan jalan landai adalah tinggi $1 \mathrm{~m}$ sebanding dengan panjang $12 \mathrm{~m}$. Lihat Peraturan Menteri Pekerjaan Umum dan Pekerjaan Rakyat Republik Indonesia Nomor 14/PRT/M/2017 tentang Persyaratan Kemudahan Bangunan Gedung

33 Pemasangan guiding block seharusnya dipasang sejajar dengan lantai yang lain, dan bukan dipasang di atas lantai yang telah ada sebelumnya. Ibid.

34 Standarnya, toilet jongkok dipasang dengan ketinggian $40 \mathrm{~cm}$ (sesuai dengan tinggi kursi roda mobilitas) dengan pintu geser (bukan pintu dorong). Ibid.

35 Wawancara dengan Pak Waryono (Wakil Rektor III UIN Sunan Kalijaga) bertempat di gedung perkuliahan UIN Sunan Kalijaga, tanggal 20 November 2019
} 
Pandangan ini memperlihatkan bahwa kebijakan pembangunan masih menggunakan pendekatan ekslusi, bukan inklusi. Penyandang disabilitas dan bukan penyandang disabilitas masih dilihat sebagai dua kelompok yang berbeda, sehingga masing-masing harus diberi akses yang berbeda. Pendekatan inklusi mendorong agar pembangunan dilakukan dengan menggunakan standar universal design. Fasilitas dibangun agar bisa digunakan oleh semua orang, baik orang dengan disabilitas maupun tanpa disabilitas, dengan menghilangkan hambatan yang mungkin muncul dengan proto type bangunan tersebut. Penyediaan toilet duduk dengan pintu geser yang ringan bukan hanya bisa digunakan oleh pengguna kursi roda, namun juga memudahkan bagi orang lanjut usia (elderly), orang dengan obesitas, orang yang sedang sakit, dan perempuan yang hamil. Di sini paradigma universal design perlu dikembangkan di perguruan tinggi.

\section{Layanan Bagi Penyandang Disabilitas Berbasis Personal Empathy}

Mahasiswa penyandang disabilitas di perguruan tinggi di Yogyakarta pada umumnya mendapatkan layanan yang baik dan tidak mengalami perlakuan yang merendahkan martabat mereka. Situasi ini terwakili dalam pernyataan berikut: ${ }^{36}$

Kalau teman-teman semua responnya bagus ya positif, tapi kalau dosen ya satu dua ya bagus, namun ada juga yang cuek, begitu pun di Tata Usaha ada beberapa yang cuek. Tapi untuk tindakan diskriminasi atau bully tidak ada. Untuk pembelajaran, saya disamakan baik di kelas, penilaian dan lainya dengan mahasiswa non-disabilitas. Layanan ketika ujian juga sudah bagus seperti ketika kita ujian tulis kita bisa minta ujian mandiri, jadi nanti bisa dibacakan dan diberi waktu sendiri.

Layanan yang baik tersebut terlihat sebagai perlakuan yang muncul karena empati individu dan belum menjadi standar pelayanan berdasarkan pengetahuan mengenai etiket berinteraksi yang memadai. Hal ini terwakili dalam pernyataan berikut: ${ }^{37}$

Intinya kita sebagai manusia harus selalu aware sih. Dan saya sering memberi tahu mahasiswa lainnya bahwa di antara kita ada yang berbeda dan itu tidak masalah.

36 Wawancara dengan Ahmad (mahasiswa difabel netra di UIN Sunan Kalijaga) pada tanggal 19 November 2019. Hal senada dinyatakan oleh Amin (mahasiswa difabel daksa di UIN Sunan Kalijaga) pada 18 November 2019

37 Wawancara dengan Dini Fitri (Dosen FEBI) bertempat di gedung perkuliahan UIN Sunan Kalijaga, tanggal 19 November 2019. Hal senada disampaikan Nanda (Dosen Fakultas Hukum UAJY) bertempat di gedung perkuliahan Fakultas Hukum UAJY, tanggal 20 November 2019 


\section{Klaim Universalitas Jaminan Hukum dan Prosedur}

Perguruan tinggi pada umumnya belum memiliki produk hukum yang berisi substansi dan prosedur layanan bagi penyandang disabilitas. Perguruan tinggi merujuk pada peraturan yang bersifat umum, misalnya peraturan tentang tata tertib, yang melarang dilakukannya kekerasan atau bullying, namun belum mengakomodasi aspek-aspek spesifik pengarusutamaan pendidikan inklusi. Hal ini terwakili dalam pernyataan Waryono: ${ }^{38}$

Peraturan internal kami punya tata tertib, walau tidak secara khusus, tapi kami sudah mendeklarasikan kampus inklusi. Maka dari itu kami memfasilitasi mahasiswa-mahasiswa difabel itu sesuai dengan kemampuan kami, seperti akses terhadap perpustakaan, sarana dan prasarana jalan semacam itu juga turut kami penuhi. Walau boleh jadi belum maksimal ya, termasuk ketika ujian masuk juga kita fasilitasi.

UIN Sunan Kalijaga adalah satu perguruan tinggi yang telah mengembangkan standar operating procedure layanan bagi penyandang disabilitas. Standar ini dikawal dan dikembangkan oleh Pusat Studi Layanan Difabel (PSLD). PSLD juga yang diberi kewenangan untuk melakukan sosialisasi serta pelatihan kepada stake holder layanan pendidikan di UIN Sunan Kalijaga. ${ }^{39}$

\section{Layanan Teknologi Informasi yang Belum Memadai}

Proses penyelenggaraan pendidikan serta layanan pendukung di semua perguruan tinggi diselenggarakan menggunakan standar "kenormalan". Perkuliahan diselenggarakan dengan mekanisme oral, penyediaan bahan ajar tercetak, perpustakaan dengan buku tercetak, dan layanan dengan standar dokumen tercetak. Situasi ini menghambat bagi penyandang disabilitas netra dan tuli untuk mengakses pendidikan tinggi. ${ }^{40}$

Upaya lebih maju dilakukan oleh UIN Sunan Kalijaga yang menyediakan disability corner di perpustakaan dengan layanan huruf braile dan screen reader.

\footnotetext{
38 Wawancara dengan Pak Waryono (Wakil Rektor III UIN Sunan Kalijaga) bertempat di gedung perkuliahan UIN Sunan Kalijaga, tanggal 20 November 2019

39 Wawancara dengan Arif (Ketua Pusat Layanan Difabel (PLD) UIN Sunan Kalijaga), tanggal 20 November 2019

40 Wawancara dengan Tio Tegar Wicaksono, mahasiswa difabel netra UGM, di Working Space, pada 27 November 2019, dan Gugup Kismono di Ruang Sekretaris Rektor UGM, pada 10 Desember 2019
} 
Namun, hal ini belum menjadi kebijakan yang merata di seluruh perguruan tinggi di Yogyakarta. ${ }^{41}$

\section{Ketersediaan Sumber Daya yang Terbatas}

Sumber daya yang digunakan secara umum merujuk pada apa yang memang telah ada dan belum ada upaya serius untuk membangun kebijakan baru berdasar data dan pengetahuan yang memadai tentang disabilitas. Sumber daya ini merujuk pada ketersediaan anggaran dan sumber daya yang memadai dalam rangka memberikan layanan bagi penyandang disabilitas.

Belum tersedia laporan asesmen mengenai kebutuhan penyelenggaraan pendidikan bagi penyandang disabilitas secara umum. Asesmen adalah tindakan wajib dalam rangka menyiapkan skema penganggaran serta penyediaan sumber daya manusia (dosen dan tenaga kependidikan) agar pendidikan tinggi dapat diakses bagi penyandang disabilitas. Universitas Gajah Mada adalah universitas yang telah mencoba membangun data base, namun dianggap belum memiliki daya dorong yang memadai terhadap perubahan layanan. ${ }^{42}$

\section{Analisis Pemenuhan Hak atas Pendidikan Bagi Penyandang Disabilitas pada Perguruan Tinggi di Yogyakarta}

Hukum hak asasi manusia, secara generik, memberikan tiga jenis kewajiban kepada negara yaitu kewajiban untuk memenuhi, kewajiban untuk melindungi, dan kewajiban untuk menghormati. Penelitian ini dilakukan, hanya, untuk memotret pelaksanaan satu kewajiban yaitu pemenuhan hak atas akses pendidikan tinggi. Kewajiban untuk memenuhi (Obligation to fulfill) hak asasi manusia dimaknai sebagai kewajiban negara untuk mengambil langkah legislatif, administratif, judisial, dan kebijakan praktis untuk memastikan hak-hak yang menjadi kewajibannya dapat terpenuhi hingga pencapaian maksimal. ${ }^{43}$

${ }^{41}$ Wawancara dengan Waryono (Wakil Rektor III UIN Sunan Kalijaga), pada 20 November 2019. Lihat juga Ridho Agung Juwantara, Pemenuhan Hak Difabel di UIN Sunan Kalijaga dan Universitas Atma Jaya Yogyakarta, INKLUSI: Journal of Disability Studies, Vol. 7, Nomor 2, July-December 2020, UIN Sunan Kalijaga Yogyakarta

42 Dinyatakan oleh Tio Tegar Wicaksono (mahasiswa difabel netra pada Fakultas Hukum UGM) dan di Working Space Ruang Kerja pada 27 November 2019. Hal ini diperkuat oleh Handayani (Penyandang Disabilitas Daksa, Dosen di Fakultas Ekonomika dan Bisnis UGM dan Ketua untuk Pokja Unit Layanan Disabilitas UGM, pada 10 Desember 2019. Pernyataan serupa disampaikan oleh Gugup Kismono (Sekretaris Rektor UGM) pada 10 Desember 2019

43 Manfred Nowak, ... Op. Cit., hlm. 48, dan Eko Riyadi, ... Op. Cit., hlm. 69 
Meminjam penjelasan di atas, pada konteks penelitian ini, indikator pemenuhan hak atas akses pendidikan tinggi antara lain ketersediaan peraturan, ketersediaan kebijakan administratif, kebijakan judisial, dan kebijakan praktis. Dari keempat indikator tersebut, indikator judisial tidak digunakan karena memang tidak relevan untuk menguji praktik di internal perguruan tinggi.

\section{Regulasi Pendidikan yang Bersifat Umum}

Perguruan tinggi di Yogyakarta secara umum masih gagap dengan kebutuhan baru untuk memberikan layanan pendidikan yang aksesibel bagi penyandang disabilitas. Pemberian fasilitas dan layanan sosial yang diberikan masih bersifat tanggap darurat, coba-coba, dan berbasis pada kebutuhan aktual. Perguruan tinggi belum memiliki regulasi, tata kelola, panduan umum, dan standar.

Terdapat dua pendekatan yang dapat digunakan terkait regulasi yaitu regulasi khusus dan regulasi inklusif. Regulasi khusus adalah peraturan yang dibuat oleh pengelola lembaga pendidikan tinggi dalam rangka memberikan layanan yang aksesibel bagi penyandang disabilitas. Regulasi ini dibuat secara khusus agar mencakup semua kebutuhan perbaikan dan pengembangan sarana dan prasarana fisik serta layanan sosial dalam rangka memenuhi hak penyandang disabilitas dalam rangka mengakses layanan pendidikan tinggi. Pembuatan regulasi ini lebih cepat, namun memiliki kekurangan dalam aspek inklusivitasnya. Regulasi khusus ini justru akan memunculkan eksklusifisme karena memunculkan ruang khusus bagi penyandang disabilitas.

Model kedua adalah regulasi inklusif. Hal yang perlu dilakukan oleh penyelenggara perguruan tinggi adalah meninjau ulang peraturan-peraturan pokok untuk kemudian dimasukkan (inserting) pasal-pasal baru yang berisi perintah untuk melakukan penyesuaian (adjustment) seluruh aspek layanan, baik layanan fisik maupun layanan non-fisik, agar perguruan tinggi dapat diakses oleh penyandang disabilitas. Proses ini relatif lebih rumit dan butuh keseriusan dalam rangka penulisannya, namun proses inilah yang justeru akan membuat pemahaman pengelola perguruan tinggi komprehensif dan layanan yang akan dikembangkan akan bersifat inklusif. 
Penelitian ini menunjukkan bahwa hampir semua perguruan tinggi di DIY belum memiliki dua model regulasi di atas. Perguruan tinggi di DIY menggunakan regulasi yang menggunakan pendekatan "normalitas."44 Jika ada mahasiswa penyandang disabilitas yang diterima, maka kebijakan yang dikembangkan adalah "kebijakan khusus" sekedar untuk membantu mahasiswa yang bersangkutan. Sudah saatnya perguruan tinggi memulai perubahan dengan membuat regulasi yang inklusif demi terpenuhinya akses pendidikan tinggi bagi penyandang disabilitas.

\section{Kebijakan Administratif Belum Memadai}

Terdapat tiga poin utama yang ditemukan terkait kebijakan yaitu diseminasi baru bersifat informatif dan belum tersedia kebijakan inklusif, belum tersedia data mahasiswa disabilitas, dan belum tersedia Unit Layanan Disabilitas.

Perguruan tinggi menyatakan bahwa mereka telah melakukan diseminasi tentang hak penyandang disabilitas. Diseminasi dilakukan untuk memberikan informasi bahwa penyandang disabilitas harus diperlakukan dengan baik dan untuk menghindari perundungan dari dosen, tenaga administratif, dan mahasiswa. Diseminasi ini bersifat informatif dan belum mengarah ke penyelenggaraan pendidikan tinggi dengan spirit inklusi. Hal yang perlu dilakukan oleh perguruan tinggi adalah melakukan pelatihan etiket berinteraksi, pengembangan sarana dan prasarana layanan yang inklusif, penyediaan dan penguatan keterampilan mendidik secara inklusif, dan penyediaan fasilitas pendukung pembelajaran yang aksesibel.

Perguruan tinggi memiliki tanggung jawab untuk memperbaiki layanan dengan training sistematis dan aplikatif. Saat ini, baru Universitas Islam Negeri (UIN) Sunan Kalijaga yang telah memiliki sistem pelatihan bagi dosen dan tenaga administrasi kampus. Training tersebut diberikan kepada tenaga administrasi yang bertugas di banyak bisnis proses, mulai dari pendaftaran, penyedia administrasi pendidikan, dan dosen pengajar. Walau demikian, Pimpinan UIN

${ }^{44}$ Kesimpulan ini senada dengan penelitian yang dilakukan pada 2013 oleh Ahmad Soleh, "Kebijakan Perguruan Tinggi Negeri Yogyakarta terhadap Penyandang Disabilitas", Jurnal Pendidikan Islam, Volume IIII, Nomor 1, Juni 2014/1435 
masih mengakui bahwa training tersebut belum sempurna dan masih memerlukan upaya pengembangan terus-menerus. 45

Studi ini menemukan bahwa tidak ada perguruan tinggi yang memiliki data akurat tentang jumlah penyandang disabilitas yang menjadi mahasiswa di kampus tersebut. Situasi ini terjadi karena perguruan tinggi belum memiliki pengetahuan yang memadai tentang apa yang dimaksud penyandang disabilitas dan layanan apa yang harus disediakan dan diberikan bagi mereka. Penyelenggara pendidikan tinggi lebih banyak melihat dan mengenali disabilitas dari sisi fisiknya saja, seperti pengguna kursi roda, pengguna kruk atau orang yang menggunakan tongkat sebagai penanda bahwa mereka adalah orang dengan hambatan penglihatan.

Ketiadaan data mengenai jumlah mahasiswa dengan disabilitas dan ragam disabilitasnya ini tentu berpengaruh terharap semua program layanan dan pengembangan yang dimiliki kampus. Perguruan tinggi belum memiliki skema program yang dikembangkan dalam rangka memenuhi hak penyandang disabilitas untuk mengakses pendidikan tinggi. Data base yang memadai sangat diperlukan untuk menyiapkan seperangkat kebutuhan, baik yang bersifat fisik maupun layanan sosial.

Undang-Undang Nomor 8 Tahun 2016 tentang Penyandang Disabilitas memerintahkan agar penyelenggara pendidikan tinggi membuat Unit Layanan Disabilitas (ULD) untuk memastikan perguruan tinggi bisa diakses dan mau serta mampu memberikan layanan bagi penyandang disabilitas dengan spirit kesetaraan (equality). Spirit ini tidak hanya berupa pemberian layanan yang memadai, namun juga penciptaan lingkungan yang inklusif sehingga penyandang disabilitas, apapun ragam disabilitasnya, dapat mengakses layanan pendidikan tinggi dengan merdeka, mandiri, dan berdaya guna. ULD menjadi unit yang akan mengembangkan standar, norma, perbaikan layanan fisik, penyiapan tenaga pengajar maupun administrasi, dan fasilitas penunjang (sarana

45 Wawancara dengan Pak Waryono (Wakil Rektor III UIN Sunan Kalijaga) bertempat di gedung perkuliahan UIN Sunan Kalijaga, tanggal 20 November 2019 
perpustakaan, ruang terbuka, tempat olah raga) yang semuanya dapat diakses secara setara oleh penyandang disabilitas.

Perguruan tinggi di Yogyakarta secara umum belum memahami kewajiban menyediakan ULD. Secara umum, belum tersedia ULD kecuali di UIN. UIN telah memiliki ULD dengan nama Pusat Studi Layanan Difabel yang dilembagakan secara struktural dan berada di bawah Lembaga Penelitian dan Pengabdian Kepada Masyarakat (LP2M) UIN Sunan Kalijaga. UGM telah memiliki Kelompok Kerja yang bertugas menyiapkan perubahan yang diperlukan dalam rangka memberikan layanan bagi penyandang disabilitas, namun hingga kini belum dapat melembagakan ULD sebagaimana perintah Undang-Undang.

\section{Kebijakan Praktis yang Sekedar Empati dan Simbolis}

Para penyelenggara pendidikan tinggi pada umumnya belum memiliki pengetahuan dan pemahaman yang memadai tentang hak-hak penyandang disabilitas serta bagaimana memberikan layanan bagi mereka. Keterbatasan pengetahuan ini terjadi pada personal penyelenggara dan pada istitusinya. Terdapat dua hal penting yang hendaknya dikembangkan oleh perguruan tinggi yaitu pengetahuan dan keterampilan. Pelayanan seringkali dilakukan masih menggunakan dasar empati personal dan belum menjadi standar dan budaya pelayanan yang inklusif.

Pengetahuan dan pemahaman menjadi dasar bagi perubahan pola pikir (mind set). Pelayanan bagi disabilitas yang selama ini diposisikan sebagai layanan berbasis belas kasih (charity-based) harus diubah menjadi pelayanan berbasi hak (rights-based). Penyandang disabilitas bersekolah dan mengakses layanan pendidikan tinggi bukan karena sivitas kampus memberikan derma kepada mereka, namun karena memang mereka berhak untuk mendapatkan semua akses tersebut. Dengan demikian, layanan bagi penyandang disabilitas akan diposisikan sebagai layanan dasar dan merupakan kewajiban bagi penyelenggara pendidikan tinggi.

Hal kedua yang juga penting adalah keterampilan. Pengetahuan yang baik perlu dilengkapi dengan keterampilan mengenai bagaimana etiket dan pola interaksi dengan penyandang disabilitas. Tidak semua pengguna kursi roda membutuhkan bantuan, maka orang yang hendak membantu seyogyanya 
bertanya kepada yang bersangkutan apakah membutuhkan bantuan dan bagaimana cara yang baik untuk membantunya. Orang dengan disabilitas kadangkala menghadapi hambatan ketika harus memahami substansi tertentu dengan bahasa oral, maka perlu keterampilan bahasa isyarat untuk membantu mereka. Keterampilan ini perlu diajarkan kepada semua sivitas akademika, yang dimulai dengan dosen dan tenaga kependidikan. Dengan pelatihan yang memadai, maka dalam jangka panjang, mahasiswa juga akan belajar mengenai bagaimana berinteraksi, membantu, memberikan dukungan, serta menciptakan suasana belajar yang inklusif.

Satu kampus yang telah mendeklarasikan diri sebagai kampus inklusif adalah UIN Sunan Kalijaga. Penyelenggara pendidikan di UIN telah mencoba membuat berbagai macam upaya dalam rangka memenuhi dan memberikan layanan yang aksesibel bagi penyandang disabilitas. UIN juga telah mengembangkan standard operating procedure yang berisi bagaimana memberikan layanan kepada penyandan disabilitas mulai dari pendaftaran, penempatan, proses kuliah dan tahap ujian. Namun, pengelola UIN mengakui bahwa masih banyak hal yang perlu diperbaiki seperti meningkatkan keterampilan bagi dosen dan tenaga kependidikan. Proses ini adalah proses panjang untuk mencapai ruang pendidikan yang inklusif. ${ }^{46}$

Persoalan kasat mata yang sering menghambat penyandang disabilitas untuk mengakses layanan pendidikan tinggi adalah model bangunan. Secara umum, bangunan perguruan tinggi di Yogyakarta masih mengadopsi "standar kenormalan." Hal ini dapat dilihat dari model pintu dorong bahkan pintu berlapis, toilet jongkok, tangga berundak, tangga dengan gigi berjenjang banyak untuk ke lantai bertingkat, kursi sempit, meja informasi yang tinggi, goronggorong tanpa penutup, hingga belum tersedia guiding block dan ram. Situasi ini menyulitkan bagi pengguna kursi roda atau pengguna tongkat penunjuk jalan untuk mengakses ruang dan layanan pendidikan tinggi.

46 Wawancara dengan Radiman (Kasubbag Perlengkapan Dan Transportasi UIN Sunan Kalijaga) pada tanggal 19 November 2019 dan Arif (Ketua Pusat Layanan Difabel (PLD) UIN Sunan Kalijaga) pada tanggal 20 November 2019 
Hampir semua perguruan tinggi telah mencoba memberikan layanan fisik yang aksesibel, seperti penyediaan ram pada pintu masuk kampus, peletakan guiding block di lantai, penyediaan toilet duduk dan hand rail dengan tanda toilet aksesibel, penyediaan lif pada beberapa bagian kampus, namun selain fasilitas yang belum sesuai standar, juga terkesan simbolis. Secara berurutan, upaya pemenuhan standar yang layak dalam layanan pendidikan tinggi adalah Universitas Islam Negeri Sunan Kalijaga, Universitas Gajah Mada, Universiras Negeri Yogyakarta, Universitas Islam Indonesia, Universitas Muhammadiyah Yogyakarta, dan Universitas Atmajaya Yogyakarta.

Penyediaan ram di pintu masuk praktis tidak berguna jika tidak ada lif untuk menuju ke lantai bertingkat. Pengguna kursi roda hanya akan dapat masuk ke lantai pertama dan tidak bisa mengakses ruang kelas atau ruang administrasi yang berada di lantai dua. Penyediaan guiding block umumnya hanya di halaman depan atau parkir, namun belum merata di semua fasilitas. Tentu hal ini menyulitkan pengguna kruk untuk bisa mengakses ruang kelas.

Terdapat toilet dengan tanda aksesibel namun pintu masuknya masih pintu dorong, tidak ada ruang (space) yang cukup longgar di samping closet duduk dan lantai untuk masuk ke toilet juga berundak. Tentu pengguna kursi roda kesulitan untuk masuk ke toilet tersebut. Pada beberapa ruangan, lif telah dipasang. Namun, pemasangan lif lebih didasarkan pada jumlah tingkat gedung tersebut dan seberapa penting gedung tersebut bagi lingkungan kampus. Secara umum, lif dipasang pada gedung kampus yang tinggi dan/atau gedung di tempat pejabat tinggi kampus tesebut berkantor. Pemasangan lif belum didasari oleh perspektif aksesibilitas bagi penyandang disabilitas. Hal ini juga ditandai dengan akses menuju lif tersebut adalah lantai berundak. Lebih jauh, kuat sekali kesan bahwa perguruan tinggi memaknai aksesibilitas pendidikan tinggi hanya sebatas layanan fisik, yaitu dengan membuat jalan landai dan toilet duduk dengan tempelan tanda pengguna kursi roda pada pintunya.

Inklusivitas pendidikan tidak hanya dilihat pada fasilitas fisik, namun lebih penting dari itu adalah aspek layanan. Apakah tersedia dosen dan tenaga kependidikan yang mampu berbicara dengan bahasa isyarat, apakah tersedia komputer dengan pembaca layar atau buku berbahasa braile, apakah tersedia 
dosen dan tenaga kependidikan dengan kemampuan mendidik inklusi bagi penyandang disabilitas mental dan intelektual, dan sederet layanan lainnya.

Beberapa data menarik adalah telah dimulainya upaya untuk memberi akses bagi penyandang disabilitas. Fakultas Hukum UGM memiliki pojok disabilitas di perpustakaannya. UMY sedang memulai konsep green campus yang akan juga memenuhi akses penyandang disabilitas. UII sedang menyiapkan fasilitas fisik yang aksesibel. UIN relatif yang paling maju dalam rangka pemenuhan hak penyandang disabilitas. ${ }^{47}$ UIN menyediakan difabel repository berupa scaner dan screen reader serta beberapa buku braile bagi penyandang disabilitas netra. Masjid UIN telah dilengkapi dengan ram, guiding block dan juru bahasa isyarat pada saat khutbah jum'at. Upaya-upaya ini perlu diapresiasi untuk dikembangkan terus menerus, sehingga semua fasililtas akan dapat diakses secara setara oleh penyandang disabilitas.

\section{Penutup}

Penelitian ini menemukan gambaran utuh bahwa aksesibilitas layanan pendidikan tinggi di Yogyakarta masih jauh dari idealitas sebagaimana diamanahkan oleh perundang-undangan. Penyelengaraan pendidikan tinggi masih dilakukan menggunakan standar umum yang belum mengadopsi model bersifat inklusif. Dua kesimpulan penting dari penelitian ini adalah, pertama, aksesibilitas pendidikan tinggi bagi penyandang disabilitas masih sangat rendah. Hal ini dapat disimpulkan dari kondisi berikut yaitu pembangunan fasilitas yang aksesibel secara mobilitas masih bersifat simbolik, layanan bagi mahasiswa penyandang disabilitas dilakukan dengan basis personal empathy, perguruan tinggi masih menggunakan peraturan yang berlaku umum dan belum menjamin hak-hak spesifik penyandang disabilitas, layanan teknologi, informasi dan komunikasi dibuat dengan skema reguler dan masih menghambat penyandang disabilitas untuk mengaksesnya, kebijakan ekonomi dan sumber daya manusia yang memiliki kualifikasi masih sangat rendah bagi pemenuhan pendidikan tinggi bagi penyandang disabilitas. Kedua, perguruan tinggi belum mampu

\footnotetext{
${ }^{47}$ Dengan menggunakan indikator lain, hal ini dapat ditemukan pada penelitian Ridho Agung Juwantara, "Pemenuhan Hak Difabel di UIN Sunan Kalijaya dan Universitas Atma Jaya Yogyakarta," INKLUSI:Journal of Disability Studies, Vol. 7, Nomor 2, Juli-December 2020
} 
memenuhi hak atas akses pendidikan bagi penyandang disabilitas. Tiga indikatornya adalah perguruan tinggi belum memiliki regulasi (baik yang inklusif maupun yang khusus) untuk menjadi dasar penyelenggaraan pendidikan tinggi bagi penyandang disabilitas, kebijakan administratif juga belum memadai, dan kebijakan praktis yang sekedar empatik dan simbolik.

\section{Daftar Pustaka}

\section{Buku}

Riyadi, Eko, Hukum Hak Asasi Manusia, Perspektif Internasional, Regional dan Nasional, Rajawali Press, Depok, 2018.

Steiner, Henry J. dan Philip Alston, International Human Rights in Context: Law, Politics, Morals, Oxford University Press, New York, 2000.

Donelly, Jack, Universalis Human Rights in Theory and Practice, Cornel University Press, Itacha and London, 2003.

Asplund, Knut D., Suparman Marzuki, Eko Riyadi (ed), Hukum Hak Asasi Manusia, PUSHAM UII, Yogyakarta, 2008.

Clement, Luke dan Janet Read (ed.), Disabled People and the Right to Life: the Protectin and Violation of Disabled People's Most Basic Human Rights, Rotledge Taylor \& Francis Group, London \& New York, 2008.

Nowak, Manfred, Introduction to the International Human Rights Regime, Martinus Nijhoff Publishers, Leiden/Boston, 2002.

Windrawan, Puguh (ed.), Aksesibilitas Peradilan Bagi Penyandang Disabilitas, Pusham UII, Yogyakarta, 2015.

Wallace, Rebecca M.M. and Kenneth Dale-Risk, International Human Rights, Text and Materials, Sweet \& Maxwell, A Thomson Company, London, 2001.

Rodley, Sir Nigel, ‘United Nation Human Rights Treaty Bodies and Special Procedures of the Commission on Human Rights-Compementary or Competition', in Nisuke Ando (ed.), Toward Implementing Universal Human Rights, Festshrift for the Twenty-Fifth Anniversary of the Human Rights Committee, Martinus Nijhoff Publishers, The Netherland, 2004.

Buergenthal, Thomas, International Human Rights In Nutshell, United State of America, A Thomson Company, 2002.

\section{Jurnal}

Soleh, Ahmad, Kebijakan Perguruan Tinggi Negeri Yogyakarta terhadap Penyandang Disabilitas, Jurnal Pendidikan Islam, Volume IIII, Nomor 1, Juni 2014/1435, UIN Sunan Kalijaga Yogyakarta.

Lestari, Eta Yuni, Slamet Sumarto dan Noorochmat Isdaryanto, Pemenuhan Hak Bagi Penyandang Disabilitas Di Kabupaten Semarang Melalui 
Implementasi Convention On The Rights Of Persons With Disabillities (CPRD) Dalam Bidang Pendidikan, Jurnal Integralistik, Vol. 28, Nomor 1 (2017), Fakultas Pendidikan Kewarganegaraan, Universitas Negeri Semarang.

Hamidi, Jazim, Perlindungan Hukum terhadap Disabilitas dalam Memenuhi Hak Mendapatkan Pendidikan dan Pekerjaan, Jurnal Hukum Ius Quia Iustum, Volume 23 Issue 4, Oktober 2016.

Kurniawan, Harry, Aksesibilitas Infrastruktur Bagi Difabel, dalam Jurnal Difabel, Volume 2, No. 2, Tahun 2015.

Triutari, Indah, Persepsi Mahasiswa Disabilitas tentang Sistem Pendidikan Segregasi dan Pendidikan Inklusi, Despkriptif Kuantitatif pada Penyandang Disabilitas di Universitas Negeri Padang, Juppekhu (Jurnal Penelitian Pendidikan Khusus, Vol. 3 Nomor 3 (2014).

Anzari, Mudhafar, A Hamid Sarong, M. Nur Rosyid, Hak Memperoleh Pendidikan Inklusif terhadap Penyandang Disabilitas, Syiah Kuala Law Journal, Vol. 2(1), April 2018, Fakultas Hukum Universitas Syiah Kuala.

Juwantara, Ridho Agung, Pemenuhan Hak Difabel di UIN Sunan Kalijaya dan Universitas Atma Jaya Yogyakarta, INKLUSI:Journal of Disability Studies, Vol. 7, Nomor 2, July-December 2020, UIN Sunan Kalijaga Yogyakarta.

\section{Website}

http:/ / www.dinf.ne.jp/doc/english/intl/z15/z15009gl/z1500901.html.

http:/ / www2.agendaasia.org/index.php/information/disability-in-asean/88disability-in-southeast-asian-countries. 